\title{
Isolation procedure and preliminary characterization of toxin-producing bacteria from Japanese land leech, Haemadipsa zeylanica japonica and medicinal leech, Hirudo medicinalis
}

\author{
Shogo Masuda, ${ }^{*}$ Keiko Seki, ${ }^{*}$ Yoshiko Sumi* Kiyoshi Kobayashi, ${ }^{*}$ Junji SaKurada, ${ }^{*}$ \\ Miyo Murai, ${ }^{*}$ Akemi Usur, ${ }^{*}$ Hiroko Jitsukawa, ${ }^{*}$ Mieko IshiI, ${ }^{* *}$ \\ Shigeo Yoshiba** and Yoshimasa Kosako*** \\ ${ }^{*}$ Department of Bacteriology, and ** Department of Public Health and Environmental Medicine, \\ The Jikei University School of Medicine, Minato-ku, Tokyo 105, Japan \\ ***Japan Collection of Microorganisms, Riken (The Institute of Physical and \\ Chemical Research), Wako 351-01, Japan
}

(Received: March 3, 1993)

\begin{abstract}
Key words: leech, Haemadipsa, Hirudo, leech-inhabiting bacteria, disseminated intravascular coagulation, Pseudomonas.
\end{abstract}

\begin{abstract}
A group of toxin-producing bacteria was isolated from two species of leeches, the Japanese land leech, Haemadipsa zeylanica japonica and the medicinal leech, Hirudo medicinalis. The culture supernatant of one of the representative strains, designated as Y-1, had a property to cause acute death when it was inoculated in mice not only intravenously but also intraperitoneally. A prominent hyperemia was observed in the mouse skin especially when $\mathrm{Y}-1$ was intravenously inoculated. The lethal and hyperemic effects of Y-1 culture supernatant totally disappeared when it was heated at $100^{\circ} \mathrm{C}$ for $10 \mathrm{~min}$. The bacterium was found to belong to the Fluorescens group of the genus Pseudomonas. The present investigation revealed that these toxin-producing bacteria are prevalent among leech-inhabiting flora. Consequently it is highly probable that the acute death and the hyperemia due to product(s) of these bacteria might be associated with the blood-sucking behavior of the leech species. Another bacterium was also isolated from the medicinal leech. The bacterium was found to produce a toxic factor(s) which causes mouse death like Haemadipsa bacteria. This bacterium was found to belong to the Fluorescens group of genus Pseudomonas also.
\end{abstract}

* 益田昭吾, 関 啓子, 角 美子, 小林 潔, 掼田 純次，村井美代，日井あけ美，実川裕子：東京慈 恵会医科大学第 2 細菌学教室（干105 東京都港 区西新檑 3-25-8)

** 石井美恵子, 吉菜䇣雄：東京慈恵会医科大学環境 保健医学教室（干105 東京都港区西新灀 3-25-8)

**** 小迫芳正：理化学研究所微生物系統保存施設 （干351-01 和光市広沢 2-1）

\section{INTRODUCTION}

We expected that some indigenous bacteria might have special properties associated with blood coagulation or fibrinolysis in the intestine of blood-sucking leeches. During our 
280

investigation we successfully isolated some bacteria from the intestinal canal of leeches, Haemadipsa zeylanica japonica and Hirudo medicinalis, and preliminarily investigated some properties of these bacteria. In this communication, a detailed procedure for isolation of these bacteria from leeches and some of the results from experiments on the properties of the bacteria will be presented, and the utility of leeches and leech-inhabiting bacteria as the source of new types of toxin will be briefly discussed.

\section{Materials and Methods}

Leeches. Japanese land leeches were harvested in the suburbs of Kominato Town, Chiba Prefecture, which has been infested by Japanese land leeches for several years since 1985 (Fig. 1). They were housed in moisture-laden boxes at room temperature. Hirudo medicinalis leeches were kindly supplied by Department of Cosmetic Surgery, The Jikei University School of Medicine.

Mice: Five-week-old female ICR mice weighing between 20 and $25 \mathrm{~g}$ were purchased from Nisseizai Co., Tokyo, Japan. They were housed 10 per cage and fed ad libitum. At least 10 mice were used in order to confirm the reproducibility of the toxic property of bacterial culture supernatant.

Culture plates. In order to detect halo formation around the bacterial colony as a marker for the first selection of bacteria from Japanese land leeches, PAF plates were used. Originally the PAF plate was devised for the detection of coagulase produced by Staphylococcus aureus (Boothby et al., 1979; Hwang et al., 1989; Seki et al., 1989).

Isolation of leech-inhabiting bacteria. The body surface of a leech was sanitized with ethanol-soaked cotton swab and the leech was frozen for $2 \mathrm{hr}$ at $-20^{\circ} \mathrm{C}$; subsequently, it was refrigerated for several days at $8^{\circ} \mathrm{C}$. The leech corpse was protected from drying by sealing the leech-container with plastic tape. The leech was cut in the center into two pieces with sterilized scissors. The body fluid exuded from the cut end of the leech body was inoculated with a sterilized loop on PAF
Jpn. J. Sanit. Zool.

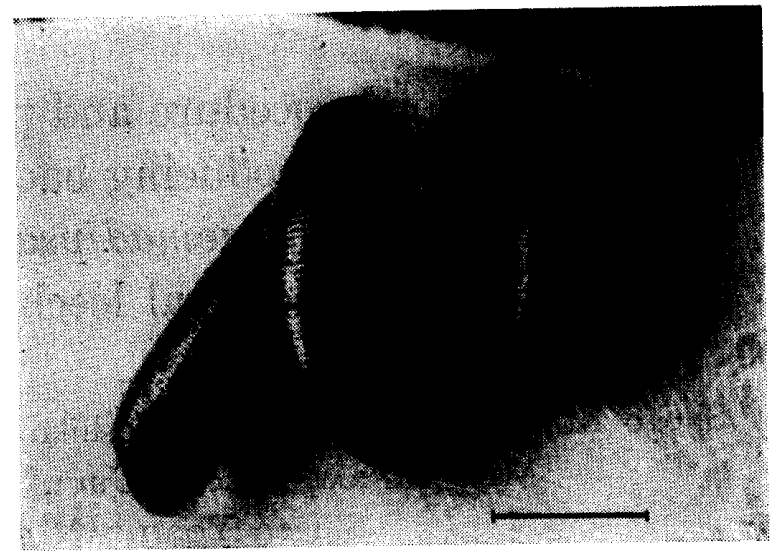

Fig. 1 Blood-sucking Japanese land leeches on an ear of rabbit excreting transcutaneously water and electrolytes.

The bar indicates $1 \mathrm{~cm}$.

plates. The plates were incubated at $25^{\circ} \mathrm{C}$ for 2 days and subjected to observation. Colonies obtained from a PAF plate with a distinctive halo around them were inoculated on NAC plates and subjected to OF test. Bacterial strains showing $O$ in $O F$ test and pigmentation were subjected to the following investigation. The same procedure for the isolation of bacteria was performed for Hirudo medicinalis. In this case, however, halo formation was not the marker for the first selection of bacteria. Bacterial colonies obtained from NAC plates were randomly subjected to toxin-production testing.

Biochemical testing. Methods used for biochemical testing were those described by Cowan (1974) and Weaver and Hollis (1983). Pigmentation was determined by growth on Pseudomonas $\mathrm{P}$ and Pseudomonas $\mathrm{F}$ agar (Difco). API $50 \mathrm{CH}$, API $50 \mathrm{AO}$ and API 50 AA strips (bioMeliux, France) were used for assimilation tests. All tests were carried out at $25^{\circ} \mathrm{C}$ and results were noted after $48 \mathrm{hr}$ of incubation unless otherwise stated.

Cellophane surface culture. The culture supernatant of the isolated bacteria was prepared by the cellophane surface culture (Ikigai et al., 1988). The bacteria were inoculated on the surface of a cellophane bag containing brain heart infusion medium set inside a glass flask and subjected to cultivation at $20^{\circ} \mathrm{C}$ for $48 \mathrm{hr}$. The supernatant of 
the bacteria-containing outer liquid was filtersterilized and harvested in another cellophane tube sealed at both ends. After extensive dialysis against phosphate buffered saline, the cellophane tube was surrounded with large amounts of polyvinylpyrrolidone at $4^{\circ} \mathrm{C}$ overnight. The culture supernatant was concentrated to about one-fifth and subjected to in vivo and in vitro toxicity tests.

Detection of toxic factors contained in concentrated culture supernatants. In the in vivo experiment, $0.2 \mathrm{ml}$ of the concentrated culture supernatant was intravenously or intraperitoneally injected to mice, and the reaction of these mice was observed. In the in vitro experiment, HeLa cells sub-confluently grown in a plastic dish (diameter $35 \mathrm{~mm}$, Nunc, Denmark) were incubated with $1 \mathrm{ml}$ of the cell-culture medium containing $1 \%$ of the concentrated culture supernatant of Y-1 strain and observed by microscope after Giemsa's staining. In parallel, dye exclusion test with trypan blue was performed.

\section{Results}

\section{Characteristics of the bacteria isolated from leeches}

Bacterial colonies with halo formation were isolated on PAF plates (Fig. 2). Colonies without halo were discarded. At the beginning, halo formation on the PAF plate was considered one of the best markers for the detection of bacteria because the formation of fibrin by them might be expected to be closely connected with blood sucking activity of the host leech. Later, however, some of toxin-producing bacteria from the Japanese land leeches were found to form no halo on the PAF plate, and none of toxin-producing bacteria from the medicinal leech were found to develop a halo on the PAF plate. The halo formation around colonies, however, was one of the most reliable markers for the isolation of the toxin-producing bacteria from Japanese land leeches. Thus, the halo-developing bacteria from Japanese land leeches were mainly investigated in the present communication. Table 1 presents the characteristics of a representative strain designated as

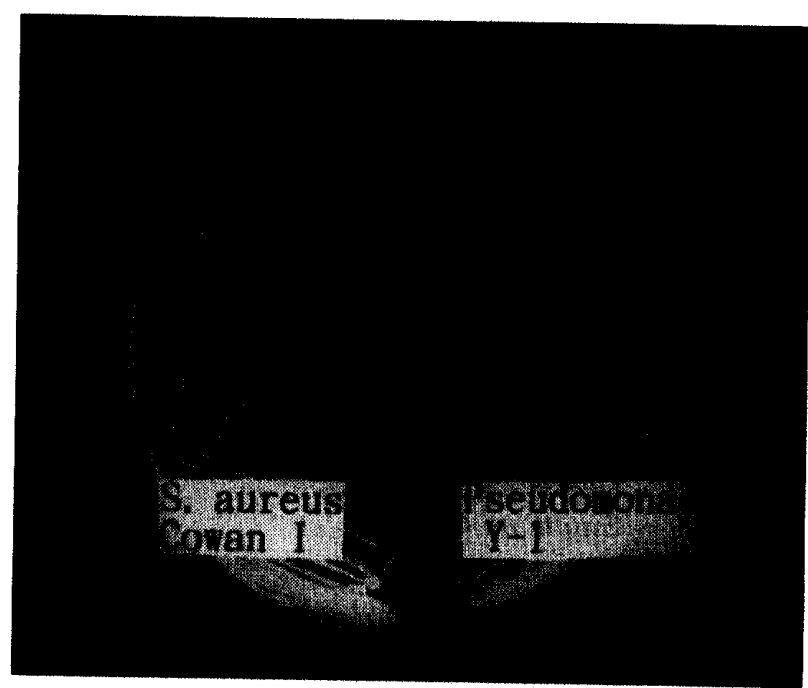

Fig. 2 Halo formation around bacterial colonies of Pseudomonas Y-1 strain on PAF plate.

Bacteria were incubated at $25^{\circ} \mathrm{C}$ for $48 \mathrm{hr}$. Colonies surrounded by a halo due to $\mathrm{Y}-1$ strain are shown on the right half of plate. For reference, colonies with a halo due to staphylocoagulase of Staphylococcus aureus Cowan I are shown on the left half of plate. Colonies of $S$. aureus are smaller than those of Y-1 partly due to the incubation temperature.

Y-1 that are commonly applied to identify Pseudomonadaceae. The Y-1 strain was Gram-negative and oxidase-positive pyoverdin producing small rod and highly motile by multi-polar flagella (Fig. 3 ). It can grow at 20 and $30^{\circ} \mathrm{C}$ but not at $37^{\circ} \mathrm{C}$. At $37^{\circ} \mathrm{C}$, the normal process of cell-division seemed to be inhibited. The enlarged and bow-shaped bacteria sometimes slowly rotated around their long axis. Under the optimal conditions the bacteria showed positive reactions for citrate (Simmon's), arginine dihydrolase, nitrate reduction and negative reactions for indole hydrogen sulfide, lysine decarboxylase, ornithine decarboxylase, urease, gelatin liquefaction and ONPG. The type of acid production from sugar is oxidative. Acid is produced from glucose, xylose, and fructose and not from lactose, maltose, sucrose or mannitol. Substrates which are utilized as the sole carbon source were shown in Table 1 also.

A few strains from the medicinal leeches were found to produce toxin to HeLa cells. 
Table 1 Phenotypic characteristics of Pseudomonas Y-1 strain.

\begin{tabular}{|c|c|c|}
\hline Test (Substrate) & & Substrate \\
\hline Motility at $25^{\circ} \mathrm{C}$ & + & Sole carbon source (continued) \\
\hline Growth at $42^{\circ} \mathrm{C}$ & - & Caprylate \\
\hline Pigmentation ( 7 days) & & Pelargonate \\
\hline Pyocianine & - & Caprate \\
\hline Pyoverdin* & + & Succinate \\
\hline Pyorubin & - & Fumarate \\
\hline Oxidase* & $t$ & Glutarate \\
\hline Indole & - & DL-Lactate \\
\hline Simmons citrate & + & DL-Glycerate \\
\hline $\mathrm{H}_{2} \mathrm{~S}$ & - & DL-3-Hydroxy-butyrate \\
\hline Lysine decarboxylase & - & L-Malate \\
\hline Arginine dihydrolase & + & Pyruvate \\
\hline Ornithine decarboxylase & - & Levulinate \\
\hline Urease & - & 2-Ketoglutarate \\
\hline Gelatin liquefaction & - & Citrate \\
\hline Nitrate to nitrite* & + & Benzoate \\
\hline Nitrate/nitrite to gas* & $t_{w}$ & D-Alanine \\
\hline ONPG & - & L-Alanine \\
\hline Type of acid from sugar* & 0 & L-Leucine \\
\hline & & L-Isoleucine \\
\hline Acid from & & L-Valine \\
\hline Glucose* & + & L-Serine \\
\hline Lactose & - & L-Phenylalanine \\
\hline Maltose & - & L-Tyrosine \\
\hline Sucrose & - & L-Histidine \\
\hline Xylose & + & L-Tryptophane \\
\hline Mannitol & 一 & L-Aspartate \\
\hline Fructose & + & L-Glutamate \\
\hline & & L-Ornithine \\
\hline \multicolumn{2}{|l|}{ Sole carbon source (positive) } & L-Lysine \\
\hline \multicolumn{2}{|l|}{ Glycerol } & L-Arginine \\
\hline \multicolumn{2}{|l|}{ Ribose } & L-Proline \\
\hline \multicolumn{2}{|l|}{ Glucose } & Betaine \\
\hline \multicolumn{2}{|l|}{ Fructose } & $\beta$-Alanine \\
\hline \multicolumn{2}{|l|}{ Mannose } & DL-4-Amino-butyrate \\
\hline \multicolumn{2}{|l|}{ Inositol } & DL-5-Amino-butyrate \\
\hline \multicolumn{2}{|l|}{$N$-Acetyl-glucosamine } & 2-Amino-benzoate \\
\hline \multicolumn{2}{|l|}{ Trehalose } & Amylamine \\
\hline \multicolumn{2}{|l|}{ Gluconate } & Ethanolamine \\
\hline \multicolumn{2}{|l|}{ 2-Keto-gluconate } & Diaminobutane \\
\hline \multicolumn{2}{|l|}{ Acetate } & Spermine \\
\hline \multicolumn{2}{|l|}{ Propionate } & Histamine \\
\hline \multicolumn{2}{|l|}{ Butyrate } & Glucosamine \\
\hline \multicolumn{3}{|l|}{ Isobutyrate } \\
\hline \multicolumn{3}{|l|}{$N$-Valerate } \\
\hline \multicolumn{3}{|l|}{ Isovalerate } \\
\hline \multicolumn{3}{|l|}{$N$-Caprolate } \\
\hline Heptanoate & & \\
\hline
\end{tabular}

w: weak reaction. ${ }^{*}$ indicates the minimum identification characteristics for the Fluorescens group of the genus Pseudomonas. 


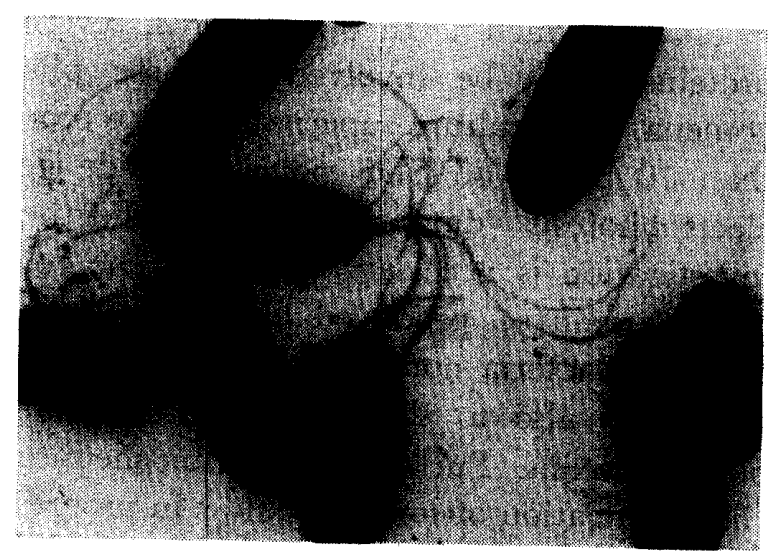

Fig. 3 Negative staining of Pseudomonas Y-1 strain.

Multi-polar flagella are seen. The bar indicates $1 \mu \mathrm{m}$.

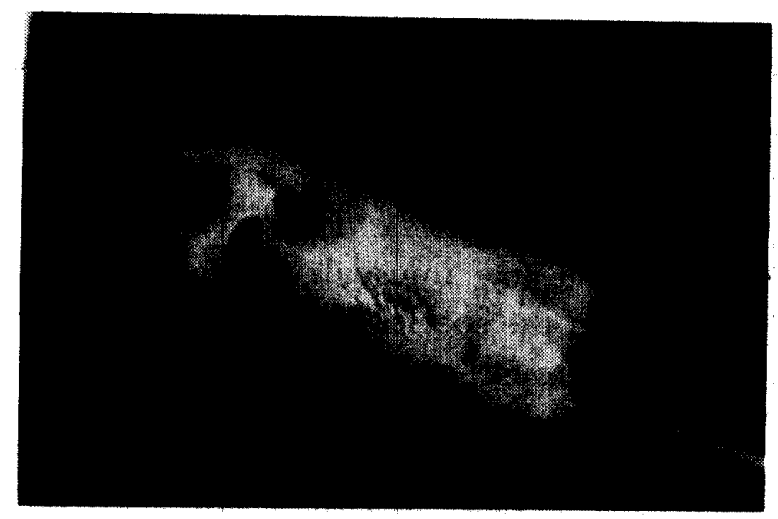

Fig. 4 The appearance of mouse killed by intravenous injection of culture supernatant of Pseudomonas Y-1 strain.

Bleeding is seen around the mouth and the external urethral orifice. The tips of forefeet are swollen and discolored by dermatological changes.

These bacteria were found to show no halo on the PAF plate and belong to the Fluorescence group of the genus Pseudomonas also.

The results of the administration of the concentrated culture supernatant of the bacteria to mice

As a tentative experiment, $0.2 \mathrm{ml}$ of the culture supernatant of the cellophane surface culture of Y-1 strain concentrated to onefifth was intravenously administered to mice through a tail vein. There was no immediate change in mouse appearance. In several minutes, however, the hairless area of their

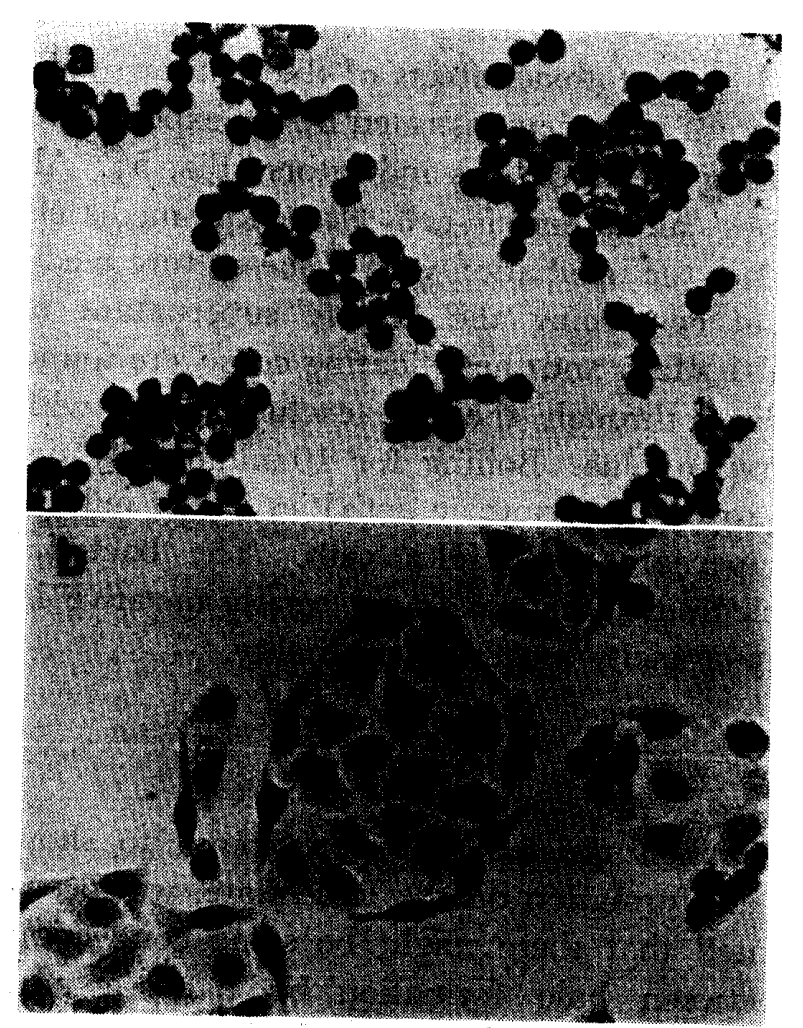

Fig. 5 Morphological changes of HeLa cells incubated with the culture supernatant of Pseudomonas Y-1 strain.

HeLa cells were stained in Giemsa's staining. a: HeLa cells treated with the culture supernatant of Y-1 strain. Cells became round-shaped and died. b: normal HeLa cells.

extremities became gradually reddish and the mice showed signs of fatigue. All of the mice died within several hours. Some of them manifested hematuria and bleeding from nose and mouth just before death (Fig. 4). The autopsy revealed that the under side of their skin was extremely red and blood in the heart was not coagulated. It was further found that their kidneys were extremely dark red and their pelves contained some amounts of blood. The intraperitoneal administration with the same dose of the culture supernatant resulted in neither reddening of the skin nor hematuria, but the mice were killed earlier than the mice having received intravenously the culture supernatant. Their intestines were bloodier than those of the intravenously administered mice. These lethal effects of the culture supernatant totally disappeared 
after 10-min heating in boiling water.

The cytotoxic effects of the culture supernatant were demonstrated by the experiments using HeLa cells as indicators (Fig. 5). Almost all adhering cells floated immediately after the incubation with tissue-culture medium containing the culture supernatant of Y-1 strain and these floating cells were found dead through the dye exclusion test with trypan blue. Boiling for $10 \mathrm{~min}$ totally destroyed the cytotoxic activities of the culture supernatant to HeLa cells. The bacterial medium itself was found totally negative in cytotoxicity and mouse lethality.

\section{Discussion}

When the bacteria were found to show halo formation on the PAF plate, we speculated that there might be some connection between halo formation by bacteria and blood-sucking behavior of the host leech. So far, however, no reliable evidence has been found as to the contribution of the haloforming property of bacteria to the bloodsucking activity of the host leech. On the other hand, the cytotoxic property of the culture supernatant is considered quite interesting especially from the ecological point of view. As one hypothesis, the cytotoxic substance(s) contained in the culture supernatant might exert anti-phagocytic activity against leukocytes contained in blood sucked by the host leech. As another hypothesis, the toxin(s) might kill neonatal leeches.

The symptoms of mice acutely killed by injection of the culture supernatant remind us of disseminated intravascular coagulation. It is probable that there might be some connection between these symptoms and the hematological phenomenon associated with blood sucking by leeches. So far, no evidence has been obtained as to the presence of the bacterial products in the leech venom secreted at the biting sites of victim animals. The cytotoxic substance(s) might be protein(s) because the substance(s) is not dialyzable through cellophane membrane and is heatlabile. It is hardly probable that the biological phenomena presented here might be due to only one factor. In other words, several proteins might be involved in these phenomena. The culture supernatant gave more than 10 bands on SDS polyacrylamide gel electrophoresis (data not shown). Further investigation is necessary to clarify the role of the toxin(s) produced by the leech-inhabiting bacteria not only to bacteria themselves but also to the host leech by using purified toxins. Purification and biochemical characterization of toxins are now in progress by. Japanese researchers using Y-1 strain donated by us. It is, however, hardly probable that the leech-associated bacteria might cause infectious diseases in warm-blooded animal, including humans, because these bacteria cannot grow at all at $37^{\circ} \mathrm{C}$.

From the phenotypical characteristics, it is clear that Y-1 belongs to the Fluorescens group of Pseudomonas. Especially it is closely related to Pseudomonas aeruginosa, $P$. fluorescens or P. putida. However, the strain Y-1 shows a few unusual characteristics to identify it at the species level such as number of flagella, growth at $42^{\circ} \mathrm{C}$ and gelatin liquefaction to $P$. aeruginosa, nitrate reduction and gelatin liquefaction to $P$. fluorescens and nitrate reduction to $P$. putida. Further study is needed to clarify the taxonomical position of the strain Y-1.

As the Pseudomonas bacteria presented here are prevalent in distribution among leeches, leeches are expected to be ample suppliers of bacteria especially interesting to toxin researchers.

\section{REFERENGES}

Boothby, J., C. Genigeorgis and M. J. Fanelli (1979): Tandem coagulase/thermonuclease agar method for the detection of Staphylococcus aureus. Appl. Environ. Microbiol., 37: 298-302.

Cowan, S. T. (1974): Cowan and Steel's Manual for the Identification of Medical Bacteria, 2nd ed., pp. 71-122, Gambridge University Press, London.

Hwang, S. M., K. Seki, J. Sakurada, M. Ogasawara, M. Murai, S. Ohmayu, K. Kurosaka and S. Masuda (1989): Improved methods for detection and serotyping of coagulase from Staphylococcus aureus. Microbiol. Immunol., 33 : 175-182.

Ikigai, H., K. Seki, S. Nishihara and S. Masuda 
(1988): Simplified method for preparation of concentrated exoproteins produced by Staphylococcus aureus grown on surface of cellophane bag containing liquid medium. Microbiol. Immunol., 32: 225-228.

Seki, K., M. Ogasawara, J. Sakurada, M. Murai and S. Masuda (1989): Altered virulence of a pleiotropic Staphylococcus aureus mutant with a low producibility of coagulase and other factors in mice. Microbiol. Immunol., 33: 981990.

Weaver, R. E. and D. G. Hollis (1983): GramNegative Organisms: An Approach to Identification (Guide to Presumptive Identification), pp. 242-287, US Department of Health and Human Services, Public Health Services, Center for Disease Control.

\section{畝 要}

ニホンヤマビルおよび医用ヒルよりの

一群の毒素産生性細菌の分離方法

ならびにこれらの細菌の細菌 学的特徴の概略について

ニホンヤマビル Haemadipsa zeylanica japonica お よび医用ヒル Hirudo medicinalis よりマウスに毒性 を有する毒素を産生する一群の細菌が分離された. 本 論文では, これらの細菌の分離法の詳細を述べるとと もに，これらの細菌が産生する毒素の検出法について も述べる.またこれらの細菌はPseudomonas 属の Fluorescens 群に属することがわかった. 